\title{
IMPACT OF ABIOTIC FACTORS OF THE ENVIRONMENT ON FUNCTIONAL HEALTH OF WOMEN OF DIFFERENT AGE GROUPS
}

\author{
O. Furdychko ${ }^{1}$, O. Mudrak ${ }^{2}$, O. Yermishev ${ }^{3}$, H. Mudrak ${ }^{4}$ \\ ${ }^{1}$ Інститут агроекології і природокористування НААН (м. Київ, Україна) \\ e-mail: agroecologynaan@gmail.com; ORCID: 0000-0002-1108-7733 \\ ${ }^{2}$ КВНЗ «Вінницька академія неперервної освіти» (м. Вінниия, Україна) \\ e-mail: ov_mudrak@ukr.net; ORCID:0000-0002-1776-6120 \\ 3 Донецький національний університет імені Василя Стуса (м. Вінниия, Україна) \\ e-mail:o.yermishev@donnu.edu.ua;ORCID:0000-0001-5854-9678 \\ ${ }^{4}$ Вінницький національний аграрний університет (м. Вінниия, Украӥна) \\ e-mail: galina170971@ukr.net; ORCID: 0000-0003-1319-9189
}

\begin{abstract}
Визначено вплив абіотичних чинників середовища на функціональне здоров'я жсінок різних вікових груп. 3'ясовано, що основним регуляторним механізмом живого організму, який забезпечує гомеостаз, є вегетативна нервова система. За зміни внутрішнього $i$ зовнішнього середовища за допомогою вегетативно-гуморальних механізмів відбувається регуляція функціональних (фізіологічних і патологічних) коливальних процесів у основних системах органів, визначаючи ступінь пристосувальної реакції організму до впливу цих чинників. Дослідження стану вегетативної нервової системи людини $\epsilon$ першочерговим завданням в умовах пристосування фізіологічних $і$ функціональних систем організму до умов життєдіяльності, в т.ч. за дії на організм патологічних чинників. Відомо, що оцінка функціонування вегетативної нервової системи може бути фізіологічним маркером виявлення механізмів індивідуальної мінливості і реагування на чинники середовища. Викладено результати досліджень впливу деяких абіотичних чинників, а саме фаз Місяия, на вегетативний баланс організму людини, співвідношення активності симпатичної нервової системи до парасимпатичної нервової системи та на функціональне здоров'я жінок різних вікових груп. Встановлено, шо вплив такого абіотичного чинника, як зміна фаз Місяия на організм призводить до достовірних змін функціональної активності і гомеостазу організму. Показники фаз місячної активності функціональних систем, дублюючи лінію норми, мають однакову спрямованість, вони відрізняються амплітудою, формують вікові особливості тонусу вегетативної нервової системи та стану функціонального здоров'я у жінок різних вікових груп.
\end{abstract}

Ключові слова: середовище, чинник, здоров'я, гомеостаз, вегетативний баланс.

\section{INTRODUCTION}

The key importance in the origin and evolution of living things on Earth are abiotic environmental factors such as natural cosmoplanetary fields, which, according to many scientists, is a kind of synergistic cradle of humanity. The parameters of the physical fields in the Earth's biosphere depend, first of all, on the dynamics of space processes. It is

(C) O. Furdychko, O. Mudrak, O. Yermishev, H. Mudrak, 2020 known that at each moment cosmogeophysical reality is determined by the activity of the Sun, the relative location of the planets, the phases of the moon, the position of the Earth in the sectoral structure of the interplanetary magnetic field, and galactic cosmic radiation. This determines the parameters of magnetic, electromagnetic, gravitational, acoustic, acoustic-gravitational, other information fields, the intensity of corpuscular flows, the electrical properties of the biosphere, in 
particular the quasi-static electric field of the Earth, weather conditions on Earth, etc. $[1 ; 2]$.

\section{ANALYSIS OF RECENT RESEARCH}

As the results of numerous scientific works testify [3-5], shifts in these parameters can alter the functioning of organisms, affecting the physicochemical properties of the body's molecules, in particular through the phenomenon of nuclear magnetic resonance, enzyme activity, biochemical reaction rate, structure and transport properties of cell membranes, activity of electro- and chemosensitive ion cells, receptors, neuronal excitability, biological rhythms and more. The evolutionary sequence of interaction of different physiological and functional systems is consistent with the external environment and determines the normal life of the whole organism [6;7].

It is known that the main regulatory mechanism of a living organism that provides homeostasis is an autonomic nervous system (ANS) [8-11].

Functional (physiological and pathological) oscillatory processes in the basic systems of organs are carried out on changes of internal and external environment by means of vegetative-humoral mechanisms, determining the degree of adaptive reaction of the organism [12]. The study of the human ANS status is a primary task in terms of adaptation of physiological and functional systems of the organism to the conditions of life, including the action of pathological factors. It is known that the evaluation of the functioning of the autonomic nervous system can serve as a physiological marker for identifying mechanisms of individual variability and responding to abiotic environmental factors [11; 13].

Ambiguous environmental factor affecting the human body is the change of phases of the moon, among them the young phase, full, first and second quarters. To date, there is no data regarding the effect of the phases of the moon on the autonomic balance of the human body, the ratio of sympathetic nervous system (SNS) activity to the parasympathetic nervous system (PNS) and functional health of the population [13].

\section{MATERIALS AND METHODS OF RESEARCH}

Changes in the physiological state of the body are manifested by the transformation of electro-skin resistance in certain functional-active zones (FAZ) of the skin, which are topographically coinciding with the course of 12 classical acupuncture meridians (functional systems) - lungs (LU), pericardium (PC), heart (HT), small intestine (SI), condition of the lymphatic system (TE), large intestine (LI), spleen and pancreas (SP), liver (LR), kidney (KI), bladder (BL), gall bladder (GB) and stomach (ST). For diagnostics, correlations between the conductivity changes in 24 representative FAZs (characterizing the state of the meridian in general) and the state of classical acupuncture meridians determining.

Using V. Makats method (functional-vegetative diagnostics (FVD), we examined 3099 women of different age, who underwent sanatorium and health improvement in sanatoriums of Ukraine. FVD was conducted twice in the morning (10.00-12.00). The bioelectric activity of 12 symmetric pairs of functionally active zones of the skin (24 FAZ), 12 on the hands and 12 on the feet were studied, reflecting the functional activity of the sympathetic and parasympathetic nervous system [10]. FVD according to the method of V. Makats and devices for its implementation are approved officially by the Ministry of Health of Ukraine «New Medical Equipment and New Methods of Diagnosis» (№ 5 from 25.12.91; № 1.08-01 from 11.01.94) and the Scientific Council of the Ministry of Health of Ukraine (No. 1.08-01 of 11/01/94).

For FVD a VITA $01 \mathrm{M}$ device is used, the voltage in the closed circuit of which does not exceed the levels of membrane potentials (1-5 $\mu \mathrm{A} ; 0.03-0.6 \mathrm{~V})$ and which does not need external energy sources for its work. It has 3 diagnostic electrodes, a base electrode acceptor of electrons (AE) - a convex plate of a special alloy, pre-coated with an oxide film $(5 \times 7 \mathrm{~cm})$ and 2 paired diagnostic electrodes (D-electron donors) in the form of a silver pair, which are located in ebonite cups with a diameter of $1 \mathrm{~cm}$ and wrapped with foam gaskets. The base electrode (BE) is fixed by 
a special belt through a wet pad (moistened with saline) in the umbilical region (central mesogastric area (0-zone) with medium density tension to create stable inspection conditions. Diagnostic electrodes (DE) are also moistened with saline. In the process of testing DE electrodes at right angles with low pressure (at the level of touch), simultaneously contact with each pair of symmetric FAZ (left-right at each extremity) within 1-4 seconds before obtaining stable indicators in microamperes. After every 3 contacts the FAZs electrodes are re-moistened with saline solution. The obtained in $\mathrm{mA}$ data FVD are converted into relative values, the obtained data are compared with the norm and it is concluded the degree of deviation from it and the level of impaired functional health [10].

Mathematical and statistical processing of the results of observations was carried out using the method of nonparametric statistics proposed by Derevyanko, 1990 to determine the magnitude of the shift of the function under study [14].

\section{RESULTS AND DISCUSSION}

It is known that during changes in the phases of the Moon, there are changes in the intensity of its lightning of the Earth, the electromagnetic field of the Earth, the gravitational interaction of the Moon, the Sun and the Earth, as well as the amplitudes of ocean tides. Reproduction, behavior, predatory activity, performance, hormone secretion, melatonin synthesis, etc. in various biological organisms, including marine and desert animals, wildlife and birds, insects and humans, vary according to the lunar phases. These factors also alter the autonomic and cardiovascular activity of higher vertebrates; the level of many factors of humoral regulation of physiological functions of an organism in different lunar phases, which underlies changes in the life activity of different living organisms [2; 7].

There is quite a lot of data on the effect of the phases of the Moon on the physical and psycho-emotional state of human. Data, obtained by Oleynikova, 2015, on the effects of planetary geomagnetic disturbances show that in the full moon the content of melatonin is lower than that of the new moon, regardless of the presence of illumination. Other factors of geomagnetic disturbances occurring in the full moon appear to play a role [5].

Surgery has observed that blood loss during surgery at the beginning of the new Moon was much smaller than at the full Moon phase, and the results of interventions and recovery were better, which is explained by the decrease in heart rate and amplitude at the beginning of the new Moon, which leads to a decrease in arterial pressure, and as each day the body's strength increases, the healing of wounds is more intense. In the phase of the full Moon, the heart works with maximum force, which leads to great blood loss. However, with each passing day the body weakens and wound healing slows down [3]. At rest, both systolic and average blood pressure were $\sim 5 \mathrm{~mm} \mathrm{Hg}$. higher in the phase of the young and full Moon, compared to the first and last quarter, the rate of heart rate was restored after exercise similarly [15].

It is known that in the phase of the young Moon people have weakness, mood worsens, adynamia increases, mental capacity and attention decrease, depressive states occur. In the phase of the full Moon a person is the strongest, excitability increases, thinking, perception of information and memory improve, activity of people with unbalanced type of nervous system significantly increases, irritability, aggressiveness, tendency to affect, conflicts, etc. appear. Hypertensives during the full Moon phase can have complications: from an increase in blood pressure to heart attacks and strokes, and the frequency of myocardial infarction increases by $11.3 \%$.

Also known about the effect of the phases of the Moon on reproductive function and the peak of ovulation and productive conception among women is at full Moon. The incidence of sudden death from cardiovascular disease is also correlated with the position of the Moon [16]. I. Sitar, based on the results of 9-year observations (from 1937 cases of 617 men and 810 women), determined that the first maximum of mortality falls on 1-2 days before the first $1 / 4$, and the second one on about 2-3 days before the phase of the second 
$1 / 4$. The first minimum mortality occurs approximately 3 days before the new Moon, and the second - one day before the new Moon. The influence of the Moon on the frequency of births, the lethality of consequences in various diseases, epileptic seizures, mental disorders, suicides and sleep disorders, etc., has been confirmed [15-17].

At the same time, there are reports that different phases of the lunar cycle did not have a significant effect on the selected physical and psychological indicators of trained athletes, but this can be attributed to a better ability to adapt to changing environmental conditions due to periodic training of athletes [7].

The study of systemic-age dependence in the female group of preschool age (PA) 3-6 years old at different phases of the moon revealed that the change of phases of the Moon on the body leads to changes in the functional activity and homeostasis of the organism (Fig. 1).

It is clearly observed that the phased activity indicators of functional systems (FS) duplicate the line of norm, differing in amplitude, that is, have the same orientation. Moreover, the presence of significant changes in the studied parameters of activity indicators of FS with the norm line indicates that the maximum differences occurred in the phases of the new and full Moon. In the new moon phase there are maximum deviations in the activity of the FS in relation to functional and age norm and are characterized by an increase in the activity in the FS of the pericardium (PC), spleen and pancreas (SP), and the bladder (BL) and decrease in the state of the lymphatic system (TE) large intestine (LI) and liver (LR) relative to the area of age functional norm. In the full moon phase there is a decrease in functional activity in the FS of the heart (HT) and small intestine (SI), and an increase in the FS of the state of the lymphatic system (TE), liver (LR), gall bladder (GB). In general, a rather chaotic pattern of functional dependencies may be related to the physiological and functional immaturity of the adaptation processes and the speed of their formation and stabilization in the body of children 3-6 years old [18]. The rapid rate of morphological and functional development of all organs and systems, the incompleteness of immunity during this period contribute to increasing the sensitivity of the organism of children to changes in environmental factors, both for environmental and physiological and pathological.

The adolescence is a transition from infant development to the adult stage of ontogeny. The transitional process of adolescence captures absolutely all levels of biological organization of the teenager from changes in the structure of the skeleton, respiratory system,

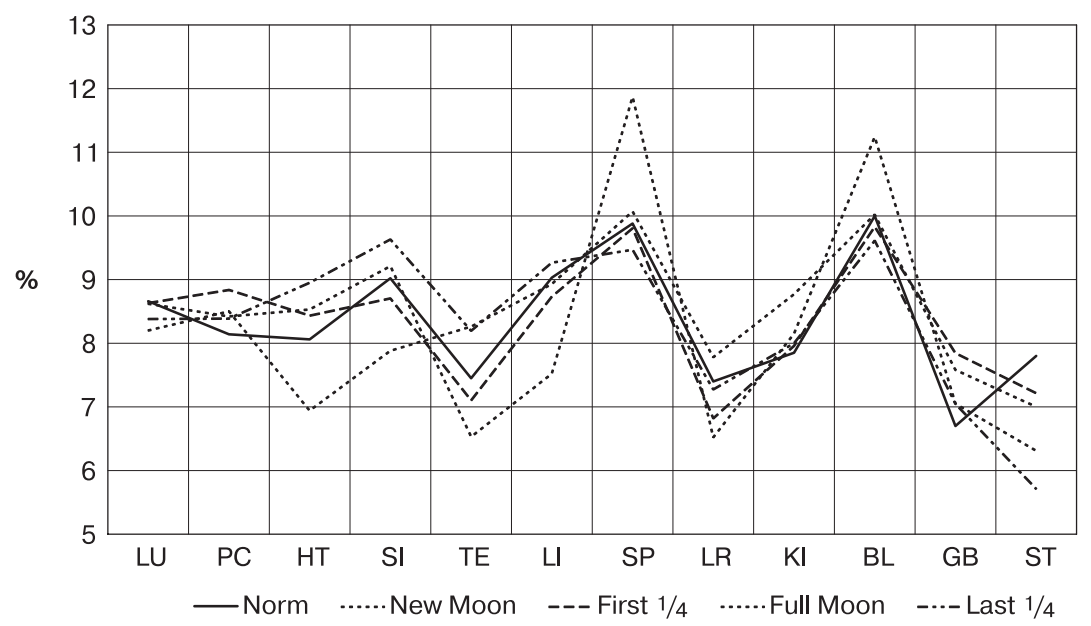

Fig. 1. Systemic age dependence in the male group of 3-6 years old (preschool age - PSA) in different phases of the Moon, $\mathrm{p} \leq 0.05$ 
circulation to the new reproductive system, its functional and structural support. There is an intensification of the activity of the pituitary gland, intensive physical and physiological development, restructuring of the motor apparatus and neurohumoral relations. The study of system-age dependence in the teenage female group (TSA) 12-15 years in different phases of the moon revealed that the change of phases of the moon on the body leads to changes in functional activity and homeostasis of the body (Fig. 2).

Changes in activity indicators of FS are observed, with much smaller amplitude, but the nature and direction of changes in activity are similar in comparison with the preschool age group. The analysis of the figure shows the stabilization of adaptation-adaptive mechanisms in the body of girls of this group of observations.

The physiological changes that take place in a person's body with age are, first and foremost, a reduction in biological functions and the ability to adapt to the effects of environmental factors and metabolic stress. At the age of 20, the rate of nerve impulse, renal function, cardiovascular function, muscle strength, healthy volume and lung capacity reach a maximum of $100 \%$. From the age of 30 , a gradual decline in the level of functio- ning of the body's physiological systems begins.

It is worth noting that the impairment of each of the body's functions is uneven. Thus, the vital capacity of the lungs significantly decreases with age $(20$ years old $-100 \%$, 40 years old $-74,60$ years old $-50,80$ years old $-25 \%$ ). And the rate of passage of the nerve impulse at the age of 20 years old is $100 \%$, for almost 40 years it is almost not reduced, at the age of 60 years old is $85 \%$, and at the age of 80 years old is $78 \%$.

Changes in the structure and function of the internal organs and systems of the organism occur during middle adulthood. After 50 years, the nervous system slows down. The skeleton loses its flexibility and shrinks somewhat. Coronary vessels narrow by $1 / 3$ compared to young age, the amount of blood pumped by the heart is reduced by $8 \%$ every 10 years of the adult period. Lung volume is also decreasing. Women aged 45 to 51 are usually menopausal. Menopause is accompanied by physical symptoms and intense emotional reactions. Among women after 50 years old, bone mass is intensively reduced, it is caused by deficiency in the body of estrogen, so bone fractures occur 6-10 times more often than among men. Before menopause, women are less likely than men to have car-

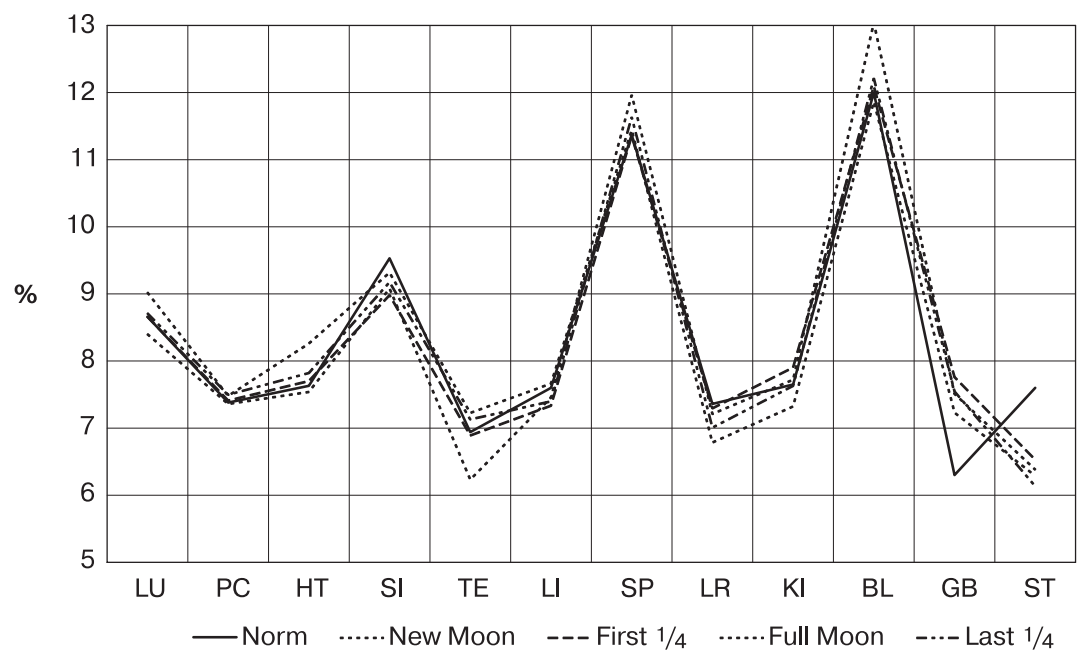

Fig. 2. Systemic age dependence in the female group of 12-15 years old (adolescent school age - ASA) in different phases of the Moon, $\mathrm{p} \leq 0.05$ 
diovascular disease, and after menopause, the risk of heart disease increases.

Studies of system-age dependence in the female adult group of mature age (MA) 21-50 years old in different phases of the Moon showed that the activity of major FS and vegetative homeostasis have a causal effect with changes in the phases of the Moon (Fig. 3). In this case, it is possible to identify specific features inherent in women of this age group. The maximum amplitude oscillations of functional activity of systems and vegetative homeostasis are observed in the new Moon. There are deviations of activity indicators of functional systems in relation to the functional-age norm and are characterized by a decrease in activity indicators in the FS of the state of the pericardium (PS), heart (HT), small intestine (SI), liver (LR) and stomach (ST), increase indicators of activity in the FS state of the lymphatic system (TE), colon (LI), spleen and pancreas (SP) and gall bladder (GB). Increase in lung FS (LU), pericardium (PS), heart (HT), lymphatic system (TE) and large intestine (LI) and decrease FS in liver (LR), kidney (KI), bladder revealed in the full moon (BL) and stomach (ST) relative to the area of age functional norm. In general, the orientation of the shift of the studied functions is similar to other age groups, but has a higher variance and randomness. Such changes in the group of observations of mature women indicate a decrease in adaptive processes associated with the age-related decline in physiological and biochemical processes in the body.

\section{ELEMENTS OF SCIENTIFIC NOVELTY}

The sympathetic orientation of the autonomic nervous system (ANS) is known to be responsible for the FS of the following: the bladder (BL), the gall bladder (GB), the stomach (ST), the small intestine (SI), the lymphatic system (TE) as well as the large intestine (LI). The parasympathetic orientation of the ANS is responsible for FS of the spleen and pancreas (SP), the liver (LR), the kidney (KI), the lungs (LU), the pericardium (PS), and the heart (HT). The relative ratio of the sum of indicators of total sympathetic activity to parasympathetic activity determines the orientation of the vegetative balance. The numerical result of this correlation is the vegetative coefficient $\mathrm{kV}$ (the autonomic nervous system coefficient), according to which seven levels of functional health dispersion are distinguished today: PAs - the zone of significant parasympathetic activity ( $\mathrm{kV}$ to 0.75 ); PAe is a zone of expressed parasympathetic activity ( $\mathrm{kV} 0.76-0.86)$; FcP is the zone of

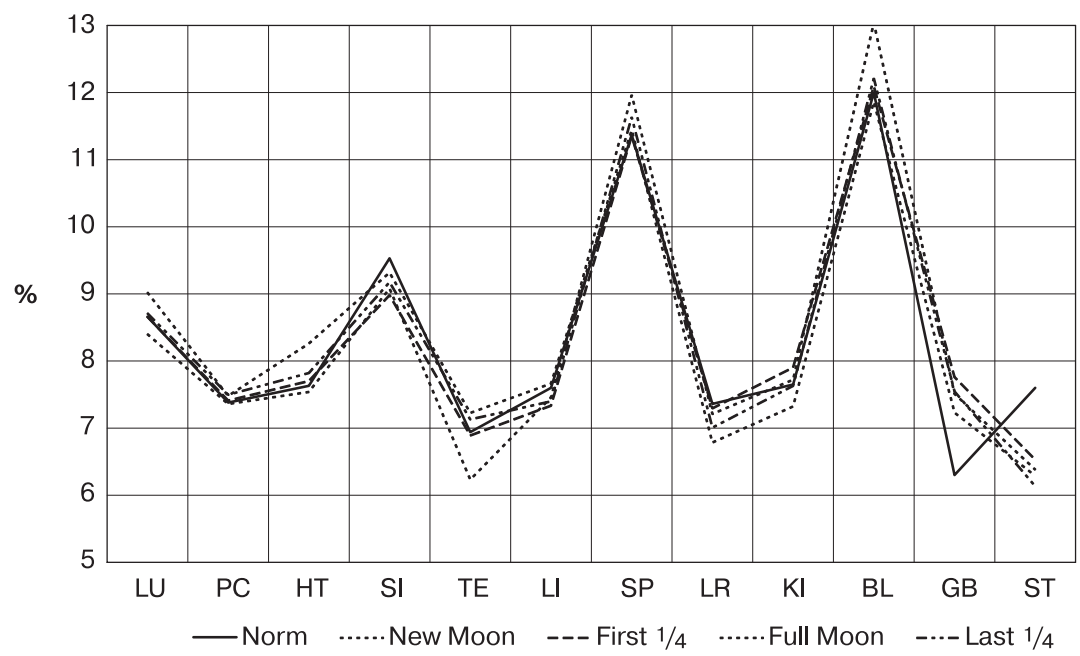

Fig. 3. Systemic age dependence in the female group of 21-50 years old (mature age $-\mathrm{MA}$ ) in different phases of the Moon, $\mathrm{p} \leq 0.05$ 
Table 1. Functional health of women of different ages (age standard)

\begin{tabular}{l|c|c|c}
\hline \multicolumn{1}{c|}{ Age groups } & $\begin{array}{c}\text { Parasympathetic activity } \\
\text { PA }(\mathrm{s}+\mathrm{e}), \%\end{array}$ & $\begin{array}{c}\text { Functional equilibrium } \\
(\mathrm{FcP}+\mathrm{VE}+\mathrm{FcS}), \%\end{array}$ & $\begin{array}{c}\text { Sympathetic activity SA } \\
(\mathrm{e}+\mathrm{s}), \%\end{array}$ \\
\hline \hline 3-6 years old (PSA) & 29.6 & 54.9 & 15.5 \\
12-15 years old (ASA) & 36.4 & 46.5 & 17.5 \\
$21-50$ years old (MA) & 46.7 & 40.8 & 12.5 \\
\hline
\end{tabular}

functional compensation of parasympathetic activity ( $\mathrm{kV} 0.87-0.94)$; VE is the zone of permissible vegetative (functional) equilibrium ( $\mathrm{kV} \mathrm{0.95-1.05);} \mathrm{FcS} \mathrm{is} \mathrm{the} \mathrm{zone} \mathrm{of} \mathrm{func-}$ tional compensation of sympathetic activity $(\mathrm{kV}$ 1.06-1.13); SAe is a zone of expressed sympathetic activity ( $\mathrm{kV} 1.14-1.26)$ and SAs is a zone of significant sympathetic activity $(\mathrm{kV}>1.26)$. It is more convenient to use vegetative dispersion (scattering) across critical zones for functional and ecological assessment of environmental factors, i.e the ratio $\mathrm{PA}(\mathrm{PAs}+\mathrm{PAe})-\mathrm{VE}(\mathrm{FcP}+\mathrm{VE}+\mathrm{FcS})-$ $\mathrm{SA}$ (SAe + SAs), which are markers of functional health. It is possible to analyze the impact on humans from the received data on the status of functional health of the population of a certain territory and averaged information on the deviation of the autonomic nervous system, both abiotic factors and possible environmental problems of the territory and its degree of ecological disturbance. As a result of research works it was found out that the main characteristic reflecting the negative influence of factors of external and internal environment is the decrease in the number of people examined in the area of functional equilibrium and their increase in the area of parasympathetic activity. According to the criteria we have developed, functional health of people is in the area of conditional norms while $70 \%$ of the population are in the area of vegetative (functional) (VE). An analysis of the obtained data revealed that no age group of men meets these requirements. This indicates a violation of functional and vegetative health and leads to disadaptation of the organism under the influence of changing conditions of the external and internal environment (Table 1).

Interesting results were obtained when analysing the effects of different phases of the Moon on functional health among women of different age groups. Significantly decreases the number of people in the VE zone in the PA group in the new moon and full moon. In the first and second phase, it rises in all observation groups. The TSA and MA groups are affected by the increase in the number of people in the VE zone. In general, PA and MA groups are more sensitive to changes in the phases of the moon on the female body, which is related to the immaturity of adaptation mechanisms in the first group and some depletion of compensatory adaptation mechanisms in the second (Table 2).

Table 2. Functional health of women of different ages in the Moon phases

\begin{tabular}{l|c|c|c|c|c|c|c|c|c}
\hline \multirow{2}{*}{ Moon phases } & \multicolumn{10}{c}{ Critical zones } \\
\cline { 2 - 11 } & \multicolumn{2}{|c|}{$\begin{array}{c}\text { Parasympathetic activity PA } \\
\text { (s + e), \% }\end{array}$} & \multicolumn{2}{c}{$\begin{array}{c}\text { Functional equilibrium } \\
\text { (FcP + VE + FcS) \% }\end{array}$} & \multicolumn{3}{|c}{$\begin{array}{c}\text { Sympathetic activity SA } \\
(\mathrm{e}+\mathrm{s}), \%\end{array}$} \\
\cline { 2 - 11 } & PA & TSA & MA & PA & TSA & MA & PA & TSA & MA \\
\hline \hline \multirow{2}{*}{ Full Moon } & 38.7 & 33.4 & 53.6 & 41.9 & 46.5 & 39.4 & 19.4 & 20.1 & 7.0 \\
Last Quarter & 32.7 & 33.5 & 48.0 & 60.4 & 53.0 & 42.5 & 6.9 & 13.5 & 9.5 \\
Moon phases & 40.0 & 30.3 & 26.6 & 36.0 & 50.4 & 53.4 & 24.0 & 19.3 & 20.0 \\
New Moon & 30.9 & 36.6 & 37.1 & 57.3 & 51.3 & 45.2 & 11.8 & 10.7 & 17.7 \\
\hline
\end{tabular}


Table 3. Moon phases. Vegetative factor k-V

\begin{tabular}{l|c|c|c}
\hline Moon phases & PA & TSA & MA \\
\hline \hline New Moon & 0.95 & 1.02 & 0.90 \\
First Quarter & 1.00 & 0.95 & 0.88 \\
Full Moon & 0.99 & 0.98 & 0.94 \\
Last Quarter & 0.95 & 0.95 & 0.94 \\
\hline
\end{tabular}

When analysing the effect of the Moon phase changes on the body of women by vegetative coefficient, it was found that the most sensitive to changes was the surveyed group of mature women. They observe a decrease in the vegetative coefficient from the norm of 0.95-1.05, with the formation of a stable parasympathicotonia, which in turn indicates the depletion of adaptation mechanisms. These effects are especially noticeable in the new Moon and the first quarter (Table 3).

\section{CONCLUSIONS}

On the basis of the conducted researches it is established that change of phases of the
Moon leads to significant changes of functional activity and homeostasis of an organism of women of different age groups.

The indicators of the phases of the monthly activity of the functional systems, duplicating the line of the norm, have the same orientation, they differ in amplitude, form the age-specific features of the tone of the autonomic nervous system and the state of functional health among women of different age groups.

The dependence of these indicators indicates the species evolutionary adaptation of humans to changes in phases of lunar activity.

\section{ЛІТЕРАТУРА}

1. Foster R.G., Roenneberg T. Human responses to the geophysical daily, annual and lunar cycles. Curr Biol. 2008. Vol 18. Issue 17. P. 784-794. DOI: https://doi. org/10.1016/j.cub.2008.07.003.

2. Chakraborty U. Effects of different phases of the lunar month on living organisms. Biological Rhythm Research. 2020. Vol. 51. № 2. P. 254-282. DOI: https://doi.org/10.1080/09291016.2018.1526502.

3. Шахненко B.I. Вплив Місяця на психічний стан, фізичну силу та розумову працездатність дітей і підлітків. Вісник Харківського нащіонального університету ім. В.Н. Каразіна. Сер.: Валеологія: сучасність і майбутне. 2008. № 818 (5). С. 112248.

4. Находкин С.С., Гончаров Н.П., Кация Г.В., Барашков Н.А. Анализ лунафазной зависимости основных гормонов эндокринной системы человека. Вестник СВФУ. 2014. Т. 11. № 2. С. 29-35.

5. Олейникова О.М. и др. Мелатонин и эпилепсия: анализ влияния геомагнитных факторов. Эпилепсия и пароксизмальные состояния. 2015. № 4. C. 29-34. DOI: https://doi.org/10.17749/20778333.2015.7.4.029-034

6. Raible F., Takekata H., Tessmar-Raible K. An Overview of Monthly Rhythms and Clocks. Frontiers in Neurology. 2017. Vol. 8. Article 189. P. 1-14. DOI: https://doi.org/10.3389/fneur.2017.00189.
7. Yousfi N. et al. Does the moon cycle affect the physical endurance, balance, reaction-time, mood state and well-being in trained athletes? J Sports Med Phys Fitness. 2020. Vol. 60(1). P. 125-131. DOI: https://doi.org/10.23736/S0022-4707.19.09940-7

8. Jänig W. Integrative Action of the Autonomic Nervous System. Neurobiology of Homeostasis. Cambridge University Press, 2008. 636 p.

9. Parashar R., Amir M., Pakhare A., Rathi P. Age Related Changes in Autonomic Functions. Journal of Clinical and Diagnostic Research. 2016. Vol.10. Issue 3. P. 11-13. DOI: https://doi.org/10.7860/ JCDR/2016/16889.7497.

10. Макац В.Г., Нагайчук В.І., Макац Є.Ф., Єрмішев О.В. Невідома китайська голкотерапія (проблеми вегетативного патогенезу). Вінниця: ТОВ «Нілан-ЛТД», 2017. T. IV. 286 с.

11. Єрмішев О.В., Петрук Р.В., Овчинникова Ю.Ю., Костюк В.В. Функціональне здоров'я дітей як екологічний біоіндикатор України / за ред. В.Г. Макаца. Вінниця: ТОВ «Нілан-ЛТД», 2017. 226 с.

12. Gerasimov A.V., Kostyuchenko V.P., Solovieva A.S., Olovnikov A.M. Pineal Gland as an Endocrine Gravitational Lunasensor: Manifestation of Moon-Phase Dependent Morphological Changes in Mice. Biochemistry (Mоsсот). 2014. Vol. 79. No. 10. P. $1069-$ 1074. DOI: 10.1134/S0006297914100083. 
13. Yermishev, O.V., Mudrak, O.V. Environmental and comparison analysis of functional health of men of different age groups in radiation contaminated and conditionally pure regions Ukraine. Біоресурси $i$ природокористування. 2019. Т. 11. № 5-6. С. 112 128. DOI: http://dx.doi.org/10.31548/bio2019. 05.012

14. Деревянко Е.А. Интегральная оценка работоспособности при умственном и физическом труде. Методические рекомендации. Москва: Экономика, 1990. 109 с.

15. Chakraborty U. Effects of different phases of the lunar month on humans. Biological Rhythm Research.
2014. Vol. 45. No. 3. P. 383-396. DOI: https://doi. org/10.1080/09291016.2013.830508

16. Zimecki M. The lunar cycle: effects on human and animal behavior and physiology. Postepy Hig Med Dosw. (online). 2006. Vol. 60. P. 1-7.

17. Näyhä S. Lunar cycle in homicides: a populationbased time series study in Finland. BMJ Open. 2019. 9:e022759. DOI: https://doi.org/10.1136/bmjopen2018-022759.

18. Yermishev, O.V. Peculiarities of functional-vegetative homeostasis of preschool-age females (first childhood). Biologija. 2019. Vol. 65. No. 1. P. 56-65. DOI: https://doi.org/10.6001/biologija.v65i1.3987

\section{REFERENCES}

1. Foster, R.G., \& Roenneberg, T. (2008). Human responses to the geophysical daily, annual and lunar cycles. Curr Biol., 18 (17), 784-794. DOI: https:// doi.org/10.1016/j.cub.2008.07.003 [in English].

2. Chakraborty, U. (2020). Effects of different phases of the lunar month on living organisms. Biological Rhythm Research, 51 (2), 254-282. DOI: https:// doi.org/10.1080/09291016.2018.1526502 [in English].

3. Shakhnenko, V.I. (2008). Vplyv Misiatsia na psykhichnyi stan, fizychnu sylu ta rozumovu pratsezdatnist ditei i pidlitkiv [Influence of the Moon on the mental state, physical strength and mental capacity of children and adolescents]. Visnyk Kharkivskoho natsionalnoho universytetu im. V.N. Karazina. Ser.: Valeolohiia: suchasnist i maibutnie - Bulletin of Kharkiv National University. VN Karazina. Ser: Valeology: present and future, 818 (5), 112-248 [in Ukrainian].

4. Nakhodkin, S.S., Goncharov, N.P., Katsiya, G.V., \& Barashkov, N.A. (2014). Analiz lunafaznoy zavisimosti osnovnykh gormonov endokrinnoy sistemy cheloveka. [Analysis of the lunar phase dependence of the main hormones of the human endocrine system]. Vestnik Severo-vostochnogo federalnogo universiteta - Vestnik of North-Eastern Federal University, 11 (2), 29-35 [in Russian].

5. Oleynikova, O.M. et al. (2015). Melatonin i epilepsiya: analiz vliyaniya geomagnitnykh faktorov. [Melatonin and epilepsy: analysis of the influence of geomagnetic factors] Epilepsiya i paroksizmalnye sostoyaniya - Epilepsy and paroxysmal conditions, 4, 29-34. DOI: https://doi.org/10.17749/20778333.2015.7.4.029-034 [in Russian].

6. Raible, F., Takekata, H., \& Tessmar-Raible, K. (2017). An Overview of Monthly Rhythms and Clocks. Frontiers in Neurology, 8, 189, 1-14. DOI: https:// doi.org/10.3389/fneur.2017.00189 [in English].

7. Yousfi, N. et al. (2020). Does the moon cycle affect the physical endurance, balance, reaction-time, mood state and well-being in trained athletes? J Sports Med Phys Fitness, 60 (1), 125-131. DOI: https://doi.org/10.23736/S0022-4707.19.09940-7 [in English].

8. Jänig W. (2008). Integrative Action of the Autonomic Nervous System. Neurobiology of Homeostasis. Cambridge University Press [in English].
9. Parashar, R., Amir, M., Pakhare A., \& Rathi, P. (2016). Age Related Changes in Autonomic Functions. Journal of Clinical and Diagnostic Research, 10 (3), 11-13. DOI: https://doi.org/10.7860/JCDR/2016/ 16889.7497 [in English].

10. Makats, V.H., Nahaichuk, V.I., Makats, Ye.F., \& Yermishev, O.V. (2017). Nevidoma kytaiska holkoterapiia (problemy vehetatyvnoho patohenezu) [Chinese acupuncture (problems of vegetative pathogenesis) is unknown]. (Vol. IV). Vinnytsia: Nilan-LTD [in Ukrainian].

11. Makatsa V.H. (Ed.), Yermishev, O.V., Petruk, R.V., Ovchynnykova, Yu.Iu., \& Kostiuk, V.V. (2017). Funktsionalne zdorovia ditei yak ekolohichnyi bioindykator Ukrainy [Functional health of children as an environmental bioindicator of Ukraine]. NilanLTD [in Ukrainian].

12. Gerasimov, A.V., Kostyuchenko, V.P., Solovieva, A.S., \& Olovnikov, A.M. (2014). Pineal Gland as an Endocrine Gravitational Lunasensor: Manifestation of Moon-Phase Dependent Morphological Changes in Mice. Biochemistry (Moscow), 79 (10), 1069-1074. DOI: https://doi.org/10.1134/S0006297914100083 [in English].

13. Yermishev, O.V., \& Mudrak, O.V. (2019). Environmental and comparison analysis of functional health of men of different age groups in radiation contaminated and conditionally pure regions Ukraine. Bioresursy i pryrodokorystuvannya - Bioresources and nature management, 11, 5-6,112-128. DOI: http:// dx.doi.org/10.31548/bio2019.05.012 [in English].

14. Derevyanko, Y.A. (1990). Integralnaya otsenka rabotosposobnosti pri umstvennom i fizicheskom trude. Metodicheskie rekomendatsii. [Integral assessment of mental and physical performance. Methodical recommendations]. Moskva: Ekonomika [in Russian].

15. Chakraborty, U. (2014). Effects of different phases of the lunar month on humans. Biological Rhythm Research, 45 (3), 383-396. DOI: https://doi.org/ 10.1080/09291016.2013.830508 [in English].

16. Zimecki, M. (2006). The lunar cycle: effects on human and animal behavior and physiology. Postepy Hig Med Dosw. (online), 60, 1-7 [in English].

17. Näyhä, S. (2019). Lunar cycle in homicides: a populationbased time series study in Finland. BMJ Open, 9:e022759. DOI: https://doi.org/10.1136/bmjopen2018-022759 [in English]. 
18. Yermishev, O.V. (2019). Peculiarities of functionalvegetative homeostasis of preschool-age females (first childhood). Biologija, 65 (1), 56-65. DOI: https://doi.org/10.6001/biologija.v65i1.3987 [in English].

Стаття надійшла до редакції журналу 08.05.2020

\title{
ВЕКТОРИ ПОДОЛАННЯ ТРАНСФОРМАЦІЙ ЕКОЛОГО-ЕКОНОМІЧНОЇ ТА СОЩІАЛЬНОЇ БЕЗПЕКИ СТАЛОГО РОЗВИТКУ НА ОСНОВІ МОДЕРНІЗАЦІЇ
}

\author{
Г.М. Калетник, С.М. Лутковська
}

\author{
Вінницький національний аграрний університет (м. Вінниия, Україна) \\ e-mail: vitontiras2017@gmail.com; ORCID: 0000-0002-4848-2796 \\ e-mail: svetvsau@gmail.com; ORCID: 0000-0002-8350-5519
}

\begin{abstract}
Представлено вектори подолання трансформацій еколого-економічної та соціальної безпеки на основі модернізації. Модернізація сектора безпеки - важлива складова комплексної модернізації України. У суспільно-політичному й соціально-економічному розвитку країни сектор безпеки виконує важливу життєву функцію - продукує одне з основних суспільних благ, а саме - безпеку, використовуючи для иього людські, матеріальні та фінансові ресурси країни. Наведений індекс міжнародного екологічного виміру EPI (Environmental Performance Index) і його індикатори визначають здатність тієї чи іншої країни захищати своє навколишнє природне середовище як у теперішньому часі, так і у довготерміновій перспективі, зважаючи на стан національної екологічної системи, можливість протидії екологічним впливам і зниження залежності людей від екологічних проявів, соціальних та інституціональних можливостей краӥни відповідати на екологічні виклики, спроможності глобального контролю над екологічним станом тощо. Визначено, що компонента безпеки життя - це інтегрована оцінка, яка враховує сумарний вплив сукупності глобальних загроз на сталий розвиток країн світу. У сучасних умовах складовою стратегії соціоприродного розвитку є екологічна модернізація. Кінцевою метою иього процесу є гармонізація всього комплексу відносин у соціально-екологічній системі, їі стійкий, збалансований розвиток, що дасть змогу у підсумку уникнути глобальної екологічної катастрофи й забезпечити процес коеволющіі людини, суспільства й природи. Одним з основних чинників низької ефективності сектора екобезпеки України є його недостатнє фінансування і низьке матеріально-технічне забезпечення, а ие - основні складові процесу технологічної модернізаціі. Проте реформування сектора безпеки залежить не тільки від збільшення фінансування. Модернізація екологічної безпеки передбачає свідомо організований процес і соціальну практику, що в сукупності сприяють поліпшенню стану навколишнього природного середовища та здоров'я людини й реалізуються через конкретні соціальні інститути та їх взаємодію.
\end{abstract}

Ключові слова: екологія, глобалізація, коеволюція, індекс екологічної ефективності, рециклінг, компонент безпеки життя.

\section{ВСТУП}

Необхідною умовою успішного розвитку країни є забезпечення комплексної безпеки ii розвитку. Це передбачає відтворення якісно нової системи національної безпеки, здатної зважати та реагувати на

(C) Г.М. Калетник, С.М. Лутковська, 2020 нові внутрішні й зовнішні виклики. Сучасна держава має швидко реагувати на екологічні й техногенні ризики, загрози фінансовій, економічній, соціальній безпеці, разом з іншими країнами брати активну участь у створенні безпечного міжнародного середовища у регіональному та глобальному вимірах. Вектори трансформацій 